Buana Sains Vol 17 No $1: 75$ - 84

\title{
KEMAMPUAN Bacillus subtilis dan Pseudomonas fluorescens DALAM MELARUTKAN FOSFAT DAN MEMPRODUKSI HORMON IAA (Indole Acetic Acid) UNTUK MENINGKATKAN PERTUMBUHAN TANAMAN TOMAT
}

\author{
Istiqomah, Luqman Qurata Aini dan Abdul Latief Abadi
}

Program Pascasarjana Fakultas Pertanian Universitas Brawijaya

\begin{abstract}
Tomato is an important horticultural commodity in Indonesia and plays strategic role in fulfilling daily needs of the public. The increase in production of tomato can be done by optimizing the provision of nutrients that support growth. The ability of bacteria as biological fertilizer to dissolve phosphate and produce IAA (Indole Acetic Acid) are important criteria for the use of bacteria as agents of plant growth promoters. The purpose of this study was to determine the ability of some isolates of Bacillus subtilis and Pseudomonas fluorescens in dissolving phosphate and produce IAA to enhance the growth of tomato. Phosphate test results showed that all isolates of B. subtilis and P. fluorescens capable of dissolving phosphate with the highest value indicated by P. fluorescens UB-PF5 $(18 \mathrm{~mm})$. All isolates of bacteria capable to produce IAA. The resulting value IAA ranged from 0.69 to $1.09 \mathrm{ppm}$ with the highest value produced by B. subtilis UB-ABS2 $(1.09 \mathrm{ppm})$. The test results on the parameters of root weight, root length, plant height and number of leaves showed that tomato treated with B. subtilis and P. fluorescens increased significant growth compared with watering only with distilled water. The highest increased root weight and root length were resulted by $P$. fluorescens UB-PF5 with values $97.10 \%$ and $64.83 \%$, respectively. The highest increased plant height and number of leaves length were resulted by P. fluorescens UB-PF6 with values 38,80\% and 30,7\%, respectively.
\end{abstract}

Keywords: Phosphate, Indole Acetic Acid, Bacillus subtilis, dan Pseudomonas fluorescens.

\section{PENDAHULUAN}

Tomat merupakan komoditas hortikultura yang penting di Indonesia dan berperan strategis dalam pemenuhan kebutuhan masyarakat sehari-hari. Tomat banyak dimanfaatkan dalam bentuk segar sebagai sayur, buah, dan dalam bentuk olahan berupa makanan. Selain itu tomat memiliki kandungan gizi tinggi seperti protein, karbohidrat, lemak, mineral, dan vitamin (Bernadus dan Wahyu, 2002). Tingginya penggunaan tomat tersebut mengakibatkan tuntutan produksi tomat yang tinggi pula. Peningkatan produksi dapat dilakukan dengan jalan mengoptimalkan pemberian nutrisi hara dan zat lainnya yang memicu pertumbuhan. Kesadaran akan perbaikan lingkungan hidup dan pengurangan penggunaan bahan kimia sintetis di bidang pertanian telah mendorong berkembangnya ilmu pengetahuan untuk menghasilkan cara alternatif yang ramah lingkungan, termasuk di dalamnya adalah pemanfaatan mikroba sebagai agen hayati penghasil senyawa tertentu yang dapat meningkatkan pertumbuhan tanaman.

Kemampuan bakteri sebagai pupuk hayati untuk melarutkan fosfat dan memproduksi hormon IAA merupakan 
kriteria penting untuk pemanfaatan bakteri sebagai agen pemacu pertumbuhan tanaman. Fosfor (P) termasuk unsur hara makro yang memiliki peran yang penting untuk pertumbuhan tanaman, namun ketersediannya dalam tanah lebih rendah jika dibandingkan dengan unsur hara nitrogen $(\mathrm{N})$, kalium $(\mathrm{K})$, dan kalsium (Ca). Kondisi ketersediaan fosfat dipengaruhi oleh lingkungan sehingga statusnya dapat berubah dari $\mathrm{P}$ yang tersedia bagi tanaman menjadi tidak tersedia (Havlin et al., 1999). Ketersediaan fosfat bagi tanaman dapat ditingkatkan dengan memanfaatkan mikroba pelarut fosfat. Penggunaan mikroba pelarut $\mathrm{P}$ sebagai pupuk hayati memiliki keunggulan, diantaranya adalah tidak mencemari lingkungan, menghalangi terjerapnya $\mathrm{P}$ oleh unsurunsur lain dalam tanah, dan menghalangi toksisitas tanaman terhadap beberapa unsur hara mikro pada tanah masam.

IAA adalah hormon yang memiliki peran penting bagi pertumbuhan tanaman sehingga sintesisnya oleh jenis bakteri tertentu merupakan suatu alasan yang menyebabkan terjadinya peningkatan pertumbuhan tanaman. IAA adalah fitohormon kelompok auksin alami dan berperan sebagai pemacu pertumbuhan tanaman (ZPT) karena berperan meregulasi banyak proses fisiologi, seperti pembelahan dan diferensiasi sel serta sintesa protein (Idris, 2007). Kandungan IAA dalam jumlah sedikit dapat berpengaruh besar terhadap pertumbuhan dan produksi tanaman. Zat pengatur tumbuh ini mampu diproduksi oleh mikroorganisme tertentu dan juga dapat dihasilkan oleh tanaman yang dapat mempengaruhi proses fisiologis tumbuhan (Hanafiah et al., 2005).

Bakteri B. subtilis dan P. fluorescens telah dikenal secara luas memiliki potensi sebagai pupuk hayati yang dapat memberi dampak positif bagi berbagai jenis tanaman. Menurut Illmer (1995) bakteri yang sering dilaporkan dapat melarutkan fosfat antara lain adalah anggota-anggota genus Mycobacterium Pseudomonas, Micrococcus, Bacillus, Flavobacterium, Enterobacter, dan Citrobacter. Namun memiliki kisaran kemampuan berbeda-beda yang dipengaruhi oleh faktor lingkungan. Rosenblueth dan Martínez-Romero (2008) yang menyatakan bahwa beberapa spesies bakteri dari genus Psendomonas, Aerobacter, Bacillus, dan Klebsiella diketahui memiliki potensi dalam mengikat nitrogen dan menghasilkan hormon IAA. Kemampuan bakteri dalam melarutkan fosfat dan memproduksi IAA dipengaruhi oleh faktor yang beragam, diantaranya adalah faktor genetik isolat bakteri yang digunakan. Untuk itu penelitian mengenai kemampuan berbagai isolat bakteri perlu dilakukan. Pemanfaatan isolat yang memiliki karakter serta kemampuan seperti di atas digunakan sebagai komposisi untuk membuat pupuk hayati majemuk.

\section{Metode Penelitian}

Uji Kemampuan B. subtilis dan P. fluorescens dalam Melarutkean Fosfat

Pengujian ini dilakukan menurut metode Thakuria et al (2004). Media yang digunakan adalah Pikovskaya. Komposisi per liter media terdiri dari glukosa $10 \mathrm{~g}$; $\mathrm{NaCl} \mathrm{0,2} \mathrm{g;} \mathrm{KCl} \mathrm{0,1} \mathrm{g;} \mathrm{MgSO}_{4} \cdot 7 \mathrm{H}_{2} \mathrm{O} 0,1$ g; $\mathrm{MnSO}_{4}$ 2,5 mg; $\mathrm{FeSO}_{4}$ 2,5 mg; Ca $\left(\mathrm{PO}_{4}\right)_{2} 5 \mathrm{~g}$; ekstrak yeast 0,5 g; $\left(\mathrm{NH}_{4}\right)_{2} \mathrm{SO}_{4}$ $0,5 \mathrm{~g}$, dan agar $15 \mathrm{~g}$. Cawan Petri yang terisi oleh media Pikovskaya dan memadat diatasnya digoreskan atau dititikkan koloni bakteri yang akan diuji. Media dengan bakteri diinkubasi selama 3-7 hari pada suhu ruang. Kemampuan melarutkan fosfat dari isolat yang diuji dievaluasi secara kualitatif berdasarkan 
terbentuknya zona bening di sekitar koloni bakteri.Uji Kemampuan B. subtilis dan P. fluorescens dalam Memproduksi IAA (Indole Acetic Acid) Uji produksi IAA dilakukan menurut metode Gordon dan Waber (1951). Media yg digunakan adalah James Nitrogen Bromothymol Blue (JNFB) dengan komposisi per liter adalah asam malat $5 \mathrm{~g} ; \mathrm{K}_{2} \mathrm{HPO}_{4} 0,6 \mathrm{~g}$; $\mathrm{KH}_{2} \mathrm{PO}_{4} 1,8 \mathrm{~g} ; \mathrm{MgSO}_{4} .7 \mathrm{H}_{2} \mathrm{O} 0,2 \mathrm{~g} ; \mathrm{NaCl}$ $0,1 \mathrm{~g}, \mathrm{CaCl}_{2} \cdot 2 \mathrm{H}_{2} \mathrm{O} \quad 0,2 \mathrm{~g} ; \mathrm{FeEDTA}$ 0,066 g; $\mathrm{KOH} 4,5$ g; mikronutrien (pepton) $2 \mathrm{ml}$; BTB 2ml. pH media 5,8. Pereaksi Salkowski yang dibuat dari $\mathrm{FeCl}_{3} .7 \mathrm{H}_{2} \mathrm{O}$ 0,5 M 7,5 ml; $\mathrm{H}_{2} \mathrm{SO}_{4}$ pekat $150 \mathrm{ml}$; aquades $250 \mathrm{ml}$.

Sebanyak 500 um bakteri B. subtilis dan P. fluorescens dibiakkan pada media JNFB cair. Bakteri diinkubasi selama 7 hari pada suhu $28^{\circ} \mathrm{C}$ pada suhu kamar $\left(28^{\circ} \mathrm{C}\right)$ kemudian diamati perubahan warna media dan $\mathrm{pH}$. Pengukuran $\mathrm{pH}$ menggunakan $\mathrm{pH}$ meter. Kultur bakteri disentrifugasi dengan kecepatan 6000 rpm selama 15 menit. Supernatan dipindakan ke tabung reaksi steril, kemudian ditambahkan pereaksi Salkowski dengan volume yang sama. Campuran supernatan dan pereaksi diinkubasi selama 60 menit kemudian diukur nilai absorbansinya pada panjang gelombang $530 \mathrm{~nm}$ menggunakan spektrofotometer. Konsentrasi IAA yang dihasilkan dihitung dengan cara memasukkan nilai absorbansi ke dalam rumus yang diperoleh dari kurva standar IAA murni.

\section{Penelitian Rumah Kaca}

Media tanam campuran tanah : kompos (1:1) disterilkan menggunakan formalin 4\% dan ditutup plastik selama 7 hari. Tanah dikeringanginkan selama 7 hari dan siap digunakan sebagai media tanam. Pembibitan dilakukan pada trey yang telah diisi dengan media tanam. Benih tomat disebar ke dalam lubang trey dan dilakukan pemeliharaan hingga tanaman tomat berumur 14 hari. Bibit tomat kemudian dipindah ke polibag berkapasitas tanah $2 \mathrm{~kg}$. Polibag yang telah ditanami bibit tomat kemudian disiram suspensi $B$. subtilis dan $P$. fluorescens sebanyak $20 \mathrm{ml}\left(10^{9} \mathrm{CFU} / \mathrm{ml}\right)$ (Huang et al., 2013). Pada penelitian panjang dan bobot akar, penyiraman inokulum bakteri dilakukan pada saat penyemaian benih tomat.

Pengamatan panjang dan bobot akar dilakukan secara desktruktif pada 21 HST (hari setelah tanam). Pengukuran bobot dilakukan dengan memotong pangkal batang tanaman tomat kemudian dibersihkan sehingga tinggal tersisa akar saja, akar yang telah dikeringanginkan kemudian ditimbang dengan timbangan digital. Pengukuran panjang akar dilakukan dengan mengukur pangkal batang bagian bawah hingga ujung akar terpanjang menggunakan penggaris. Pengamatan tinggi tanaman dan jumlah daun dilakukan 1- 5 HSI (hari setelah inokulasi).

\section{Analisis Statistik}

Penelitian di laboratorium dilakukan menggunakan Rancangan Acak Lengkap (RAL) dengan 5 perlakuan dan 4 ulangan sedangkan penelitian rumah kaca menggunakan Rancangan Acak Kelompok (RAK) dengan 6 perlakuan dan 4 ulangan. Data dianalisis menggunakan analisis sidik ragam (ANOVA), jika terdapat perbedaan yang signifikan maka dilanjutkan menggunakan uji Duncan pada taraf 5\%.

\section{Hasil dan Pembahasan}

Kemampuan B. subtilis dan P. fluorescens dalam Melarutkan Fosfat

Semua isolat bakteri mampu melarutkan fosfat. Hal ini dapat dilihat dari zona bening yang terbentuk di sekitar koloni bakteri (Gambar 1). Hasil penelitian kemampuan isolat bakteri dalam melarutkan fosfat disajikan pada Tabel 1. 
Semua isolat $B$. subtilis dan $P$. fluorescens memiliki rerata kemampuan yang sama dalam melarutkan fosfat. Zona bening tertinggi dihasilkan oleh $P$. fluorescens isolat UB-PF5 sebesar $18 \mathrm{~mm}$. Hasil ini sesuai dengan penelitian Buntan (1992) yang memperlihatkan bahwa kelompok Pseudomonas dan Enterobacter mampu meningkatkan kelarutan fosfat pada tanah ultisol. Kedua isolat B. subtilis yaitu UB-ABS2 dan UB-ABS6 mampu melarutkan fosfat dengan adanya zona bening di sekitar koloni. Hal ini sesuai dengan hasil penelitian Kundu dan Gaur (1980), dimana dalam penelitiannya menggunakan Fosfobakterin galur fosfo 24, B. substilis, Bacterium mycoides, dan $B$. mesenterricus untuk melarutkan fosfat organik (glisero fosfat, lesitin, tepung tulang) dan $\mathrm{P}$ anorganik (Ca-P, Fe-P) yang dilakukan secara in vitro. Hasilnya menunjukkan bahwa bakteri tersebut mampu melarutkan $\mathrm{FePO}_{4}, \mathrm{Ca}_{3}(\mathrm{PO} 4)_{2}$, gliserofosfat, lesitin, dan tepung tulang berturut-turut sebanyak 2-7, 3-9, 3-13, 521, dan 14\%. Mekanisme mikroba dalam mengikat $\mathrm{P}$ adalah dengan menghasilkan asam-asam organik yaitu suksinat, asam sitrat, glutamat, laktat, oksalat, malat, glioksalat, fumarat, $\alpha$-ketobutirat, dan tartarat (Alexander, 1978).

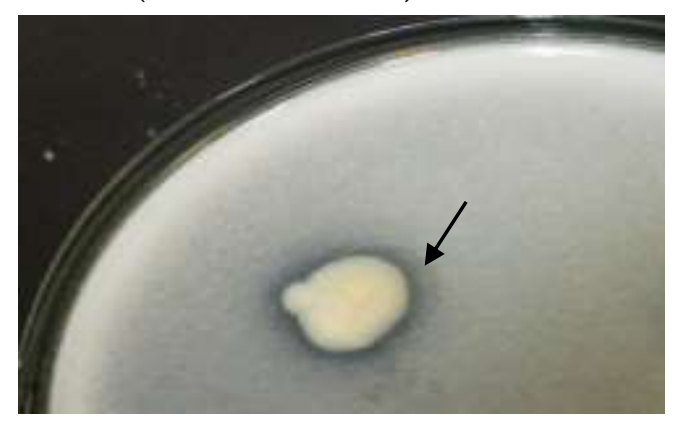

Gambar 1. Hasil uji kemampuan melarutkan fosfat $P$. fluorescens isolat UB-PF6. Tanda panah menunjukkan zona bening di koloni bakteri.

Tabel 1. Kemampuan B. subtilis dan P. fluorescens dalam melarutkan fosfat

Isolat bakteri $\quad \begin{gathered}\text { Kemampuan melarutkan } \\ \text { fosfat }\end{gathered} \quad$ Zona bening $(\mathrm{mm})$

\begin{tabular}{lcc}
\hline B. subtilis isolat UB-ABS2 & + & 15,6 \\
B. subtilis isolat UB-ABS6 & + & 15,1 \\
P. fluorescens isolat UB-PF5 & + & 18,0 \\
P. fluorescens isolat UB-PF6 & + & 15,0
\end{tabular}

Kemampuan B. subtilis dan P. fluorescens dalam Memproduksi Hormon IAA (Indole Acetic Acid)

Hasil pengamatan menunjukkan bahwa semua isolat bakteri mampu memproduksi IAA. Kelompok B. subtilis secara kuantitatif mampu memproduksi konsentrasi IAA lebih besar dibandingkan dengan kelompok $P$. flourescens walaupun selisih konsentrasinya tidak jauh antar isolat. Hasil pengamatan kadar IAA disajikan pada Tabel 2. Kandungan IAA tertinggi dihasilkan oleh $B$. subtilis UB-ABS2 sebesar 1.09 ppm. Kisaran yang tidak jauh berbeda ditunjukkan oleh isolat yang lainnya. Dengan demikian dapat 
disimpulkan bahwa semua isolat dari kedua kelompok bakteri tersebut memiliki potensi dalam menghasilkan IAA untuk mendukung pertumbuhan tanaman. Menurut Hanafiah et al (2005) beberapa golongan mikroba yang menghasilkan IAA antara lain yaitu Agrobacterium tumefaciens, Rhizobium spp., Endophyllum sempervivi, Ustilago maydis, dan P. fluorescens, mikroba tersebut menghasilkan IAA baik pada kultur murni maupun pada asosiasinya dengan tanaman (Hanafiah et al., 2005). Hal serupa sesuai dengan yang dikemukakan oleh Rosenblueth dan Martínez-Romero (2008) yang menyatakan bahwa beberapa spesies bakteri dari genus Pseudomonas, Aerobacter, Bacillus, dan Klebsiella diketahui memiliki potensi dalam mengikat Nitrogen dan menghasilkan hormon IAA.

Pembentukan indol asam asetat (IAA) dipicu oleh adanya triptofan.
Asam amino triptofan adalah komponen asam amino yang pada umumnya terdapat pada protein, sehingga dengan mudah dapat digunakan oleh mikroorganisme. Asam amino triptofan apabila dihidrolisis oleh enzim triptofamase akan menghasilkan indol dan asam piruvat (Prescott, 2002). Pada penelitian ini triptofan berasal dari pepton yang ditambahkan ke dalam media JNFB cair dan diinkubasi selama 7 hari. Hal ini dilakukan untuk mendapatkan konsentrasi IAA yang tinggi. Peningkatan produksi IAA terjadi pada saat pertumbuhan bakteri menurun dan ketersediaan karbon terbatas, hal itu terjadi saat bakteri memasuki fase stasioner. Hasil penelitian Patil et al (2011) mengungkapkan bahwa bakteri mulai menghasilkan IAA pada fase awal pertumbuhan dan mencapai hasil maksimum pada awal fase stasioner.

Tabel 2. Nilai konsentrasi IAA masing-masing isolat bakteri

$\begin{array}{ccc}\text { Isolat bakteri } & \text { Kemampuan memproduksi } & \text { Konsentrasi IAA } \\ \text { IAA } & (\text { ppm })\end{array}$

\begin{tabular}{llc}
\hline B. subtilis isolat UB-ABS2 & + & 1.09 \\
B. subtilis isolat UB-ABS6 & + & 0.69 \\
P. fluorescens isolat UB-PF5 & + & 0.93 \\
P. fluorescens isolat UB-PF6 & + & 0.84
\end{tabular}

Pengaruh B. subtilis dan P. fluorescens dalam Meningkatkan Bobot akar dan Panjang Akar Tanaman Tomat

Hasil analisis sidik ragam menunjukkan pengaruh yang nyata antara perlakuan isolat B. subtilis dan P. fluorescens terhadap bobot akar dan panjang akar tanaman tomat. Hasil pengamatan disajikan pada Tabel 3.
Pada semua perlakuan dengan aplikasi bakteri menunjukkan bobot akar yang lebih tinggi dibandingkan dengan kontrol. Bobot akar pada perlakuan dua isolat $P$. fluorescens tidak berbeda signifikan. Sementara itu, bobot akar pada perlakuan $B$. subtilis UB-ABS2 berbeda dengan perlakuan B. subtilis UBABS6. Isolat UB-ABS2 memiliki bobot 
akar yang lebih tinggi dibandingkan dengan isolat UB-ABS6. Bobot akar tomat pada perlakuan isolat $P$. fluorescens isolat UB-PF5 adalah tertinggi dibandingkan dengan seluruh perlakuan isolat yang lain dengan peningkatan bobot akar sebesar $97,10 \%$ dibandingkan kontrol.

Rerata panjang akar pada seluruh perlakuan dengan bakteri menunjukkan hasil yang lebih tinggi dibandingkan dengan perlakuan kontrol. Perlakuan kedua isolat $B$. subtilis menunjukkan panjang akar yang sama. Hal ini juga terjadi pada perlakuan dua isolat $P$. fluorescens yang juga menunjukkan panjang akar yang sama. Panjang akar tomat pada perlakuan isolat $P$. fluorescens UB-PF5 adalah tertinggi dibandingkan dengan seluruh perlakuan isolat yang lain. Panjang akar tomat pada perlakuan tersebut mengalami peningkatan panjang akar sebesar 64,83\% dibandingkan kontrol.

Penambahan panjang dan bobot akar tanaman tomat disebabkan oleh aplikasi B. subtilis dan P. fluorescens. Kedua bakteri ini mampu berkoloni di daerah perakaran dan berasosiasi dengan jaringan perakaran sehingga mempengaruhi beberapa proses fisiologis tumbuhan. Menurut Vasques et al (2000), koloni bakteri rhizosfer termasuk Azotobacter, Azosprilium, Bacillus, Clostridium dan Pseudomonas mampu memproduksi suatu senyawa yang merangsang pertumbuhan tanaman atau menghambat penyakit akar.

Kemampuan B. subtilis dan $P$. fluorescens dalam meningkatkan panjang dan bobot akar dalam penelitian ini diduga karena kemampuan bakteri tersebut dalam melarutkan fosfat dan memproduksi IAA. Hal ini terbukti melalui hasil pengamatan laboratorium yang telah dilakukan bahwa isolat-isolat tersebut mampu melarutkan fosfat dan memproduksi IAA Menurut Thakuria et al (2004), mekanisme peningkatan pertumbuhan tanaman oleh bakteri terjadi karena kemampuan bakteri dalam melarutkan senyawa fosfat, mengikat nitrogen, memicu pertumbuhan akar lateral, dan menghasilkan hormon pertumbuhan seperti hormon auksin, etilen, dan sitokinin.

Peran penting fosfat untuk tanaman adalah dalam bentuk phitin, nuklein, dan fosfatide adalah bagian dari protoplasma dan inti sel yang berperan dalam pembelahan sel. Menurut Aleel (2008), fosfat dibutuhkan oleh tanaman untuk pembentukan sel pada jaringan akar, tunas yang sedang tumbuh, dan memperkuat jaringan pada batang sehingga tanaman tidak mudah rebah.

Mekanisme bakteri dalam meningkatkan kandungan IAA pada tanaman adalah dengan menggunakan triptofan alami yang diproduksi dan dikeluarkan oleh akar kemudian digunakan untuk sintesis IAA. Menurut Leveau dan Lindow (2004), bakteri penghasil IAA terlibat dalam beberapa proses fisiologis tanaman dengan memasukkan IAA yang dihasilkannya ke tanaman, sehingga tanaman tersebut lebih sensitif dalam mengubah konsentrasi IAA yang dimilikinya. Kondisi tersebut mampu membantu proses pembentukan akar lateral, adventif, dan perpanjangan akar primer. Keterlibatan bakteri yang mampu memproduksi IAA akan meningkatkan jumlah rambut akar dan akar lateral tanaman. Hal ini juga didukung oleh hasil penelitian Lestari et al (2007) yang menyatakan bahwa IAA berpengaruh terhadap perkembangan akar gandum dan dapat memperbaiki produktivitas tanaman melalui stimulasi hormon. 
Istiqomah, L. Q. Aini dan A. L. Abadi / Buana Sains Vol 17 No 1: 75 - 84

Tabel 3. Rerata peningkatan bobot akar dan panjang akar tanaman tomat

\begin{tabular}{lcccc}
\hline \multicolumn{1}{c}{ Perlakuan } & $\begin{array}{c}\text { Bobot } \\
\text { akar (gr) }\end{array}$ & $\begin{array}{c}\text { Peningkatan } \\
\text { bobot akar } \\
(\%)\end{array}$ & $\begin{array}{c}\text { Panjang akar } \\
(\mathrm{cm})\end{array}$ & $\begin{array}{c}\text { Peningkatan } \\
\text { panjang akar } \\
(\%)\end{array}$ \\
\hline Akuades (kontrol) & $0,106 \mathrm{a}$ & - & $6,904 \mathrm{a}$ & - \\
B. subtilis isolat UB-ABS2 & $0,178 \mathrm{c}$ & 68,04 & $9,908 \mathrm{bc}$ & 43,51 \\
B. subtilis isolat UB-ABS6 & $0,156 \mathrm{~b}$ & 47,53 & $9,040 \mathrm{~b}$ & 30,93 \\
P. fluorescens isolat UB-PF5 & $0,209 \mathrm{~d}$ & 97,10 & $11,38 \mathrm{~d}$ & 64,83 \\
P. fluorescens isolat UB-PF6 & $0,202 \mathrm{~d}$ & 90,07 & $10,74 \mathrm{~cd}$ & 55,56
\end{tabular}

Keterangan : Angka yang diikuti huruf yang sama tidak berbeda nyata berdasarakan uji jarak berganda Duncan pada taraf 5\%.

Pengarub B. subtilis dan P. fluorescens terhadap Tinggi Tanaman dan Jumlah Daun Tanaman Tomat

Hasil analisis sidik ragam menunjukkan adanya pengaruh yang nyata antara perlakuan isolat-isolat $B$. subtilis dan $P$. fluorescens terhadap tinggi tanaman dan jumlah daun tomat. Rerata tinggi dan jumlah daun tanaman tomat disajikan pada Tabel 4.

Hasil pengamatan menunjukkan bahwa rerata tinggi tanaman pada seluruh perlakuan dengan bakteri memberikan hasil yang lebih tinggi dibandingkan dengan penyiraman dengan akuades. Perlakuan B. subtilis UB-ABS6 menghasilkan tinggi tanaman yang sama dengan perlakuan bakterisida streptomycin sulfat $20 \%$. Sementara itu, perlakuan dengan B. subtilis UB-ABS2, $P$. fluorescens UB-PF5, dan P. fluorescens UBPF6 menghasilkan tinggi tanaman yang sama. Efek peningkatan tinggi tanaman yang terbesar dihasilkan oleh perlakuan P. fluorescens isolat UB-PF6 dengan persentase peningkatan tinggi tanaman sebesar 38,80\%.

Tabel 4 menunjukkan bahwa rerata jumlah daun di seluruh perlakuan isolat bakteri lebih tinggi dibandingkan penyiraman dengan air. Perlakuan $B$. subtilis UB-ABS6 menunjukkan jumlah daun yang sama dengan perlakuan bakterisida streptomycin sulfat $20 \%$. Sementara itu, perlakuan dengan $B$. subtilis isolat UB-ABS2, P. fluorescens isolat UB-PF5 dan $P$. fluorescens UB-PF6 menghasilkan jumlah daun yang sama. Persentase peningkatan jumlah daun yang terbesar dihasilkan oleh $P$. fluorescens UB-PF6 yaitu sebesar $30,7 \%$ dibandingkan kontrol.

Hal yang diduga mempengaruhi peningkatan pertumbuhan tanaman tomat adalah kemampuan bakteri dalam melarutkan fosfat sehingga mampu memenuhi kebutuhan fosfat bagi tanaman. Menurut Vessey (2003), beberapa Bacillus dan Pseudomonas mampu melarutkan fosfat hingga 2-3 kali lebih banyak. Bakteri tersebut menghasilkan enzim fosfatase yang merupakan enzim yang mampu mengubah senyawa fosfat organik menjadi senyawa fosfat anorganik sehingga mampu diserap oleh tanaman. 
Tabel 4. Rerata peningkkatan tinggi tanaman dan jumlah daun tanaman tomat

\begin{tabular}{lcccc}
\hline \multicolumn{1}{c}{ Perlakuan } & $\begin{array}{c}\text { Tinggi } \\
\text { tanaman } \\
(\mathrm{cm})\end{array}$ & $\begin{array}{c}\text { Peningkatan } \\
\text { tinggi } \\
\text { tanaman }(\%)\end{array}$ & $\begin{array}{c}\text { Jumlah } \\
\text { daun } \\
\text { (tangkai) }\end{array}$ & $\begin{array}{c}\text { Peningkatan } \\
\text { jumlah } \\
\text { daun (\%) }\end{array}$ \\
\hline Akuades & $57,15 \mathrm{a}$ & - & $10,9 \mathrm{a}$ & - \\
Bakterisida streptomycin sulfat & $63,82 \mathrm{ab}$ & 11,67 & $11,9 \mathrm{ab}$ & 9,63 \\
$20 \%$ & $76,05 \mathrm{c}$ & 33,07 & $13,5 \mathrm{c}$ & 24,3 \\
B. subtilis isolat UB-ABS2 & $70,75 \mathrm{bc}$ & 23,79 & $12,7 \mathrm{bc}$ & 16,5 \\
B. subtilis isolat UB-ABS6 & $77,95 \mathrm{c}$ & 36,39 & $13,6 \mathrm{c}$ & 24,7 \\
P. fluorescens isolat UB-PF5 & $79,32 \mathrm{c}$ & 38,80 & $14,2 \mathrm{c}$ & 30,7 \\
P. fluorescens isolat UB-PF6 & &
\end{tabular}

Keterangan : Angka yang diikuti huruf yang sama tidak berbeda nyata berdasarakan uji jarak berganda Duncan pada taraf 5\%.

Dugaan lain yang menyebabkan peningkatan tinggi tanaman dan jumlah daun tanaman tomat adalah peran bakteri dalam meningkatkan fitohormon auksin alami pada tanaman. Menurut Rosenblueth dan MartínezRomero (2008), beberapa spesies bakteri dari genus Pseudomonas, Aerobacter, Bacillus, dan Klebsiella diketahui memiliki potensi dalam memfiksasi Nitrogen dan menghasilkan Hormon IAA. Mekanisme bakteri dalam meningkatkan kandungan IAA pada tanaman adalah dengan menggunakan triptofan alami yang disekresikan oleh akar yang kemudian digunakan untuk sintesis IAA.

IAA adalah hormon auksin endogen yang disintesis dalam batang dan akar. Auksin merupakan salah satu jenis hormon yang dapat memacu pertumbuhan tanaman dengan meningkatkan proses elongasi sel dan perpanjangan batang seperti halnya diferensiasi sel (Tarabily et al., 2003). Di dalam jaringan tanaman, IAA disintesis terbanyak pada bagian tanaman yang sedang aktif, tumbuh, dan berkembang. Salah satu bagian yang banyak mengandung auksin adalah bagian meristem yaitu ujung tunas, ujung akar, dan kambium. Bagian lainnya adalah daun-daun muda, bagian-bagian bunga yang sedang berkembang, buah, dan tumor (benjolan pada tanaman). Auksin mendorong perpanjangan sel (sel elongation) dengan cara mempengaruhi metabolisme dinding sel. Pembentukan auksin dalam tubuh tanaman merupakan proses biokimiawi. Mekanisme kerja IAA dalam perpanjangan sel adalah IAA mendorong elongasi sel-sel pada koleoptil dan ruas-ruas tanaman. Perpanjangan sel tanaman terutama terjadi pada arah vertikal, diikuti dengan pembesaran sel dan meningkatnya bobot basah. Peningkatan bobot basah terutama karena meningkatnya pengambilan air oleh sel tersebut (Rismunandar, 1999).

\section{Kesimpulan}

Semua isolat B. subtilis dan P. fluorescens memiliki potensi melarutkan fosfat dan memproduksi IAA serta dapat meningkatkan pertumbuhan tanaman 
tomat. Isolat $P$. fluorescens UB-PF 5 memiliki kemampuan melarutkan fosfat tertinggi dan memberikan efek peningkatan bobot akar dan panjang akar tertinggi pula. Isolat B. subtilis memiliki kemampuan tertinggi memproduksi hormon IAA dan memberikan efek bagus terhadap tinggi tanaman dan jumlah daun. Isolat yang meningkatkan tinggi tanaman dan jumlah daun tertinggi adalah $P$. fluorescens UB-PF 6.

\section{Daftar Pustaka}

Aleel, K.G. 2008. Phosphate Accumulation in Plant: Signaling. J. Plant Physiol. 148 : 3-5.

Alexander, M. 1978. Introduction to Soil Microbiology. 2nd ed. Willey Eastern Limited. New Delhi.

Buntan, A. 1992. Efektifitas bakteri pelarut fosfat dalam kompos terhadap peningkatan serapan $\mathrm{P}$ dan efisiensipemupukan $\mathrm{P}$ pada tanaman jagung. Tesis. Program Pascasarjana IPB. Bogor.

Bernadus, $\mathrm{T}$ dan W. Wahyu. 2002. Bertanam Tomat. Agromedia Pustaka. Jakarta.

Gordon, S.A, and R.P. Weber. 1951. Colorimetric Estimation of Indoleacetic Acid, Plant Physiol.26 : 192-195.

Hanafiah, Anas, Napoleon, dan Ghoffar. 2005. Biologi Tanah: Ekologi dan Mikrobiologi Tanah. PT. Raja Grafindo Persada. Jakarta.

Havlin, J.L, J.D. Beaton, S.L. Tisdale, and W.L. Nelson. 1999. Soil Fertility and Fertilizers. An Introduction to Nutrient Management. Sixth ed. Prentice Hall. New Jersey.

Huang, J., Z. Wei, S. Tan, X. Mei, S. Yin, Q. Sen, and Y. Xu. 2013. The Rhizosphere Soil of Diseased Tomato Plants as a Source for Novel Microorganisms to Control Bacterial Wilt. J. Applied Soil Ecology. 72 : 79-84.

Idris, E.E., D.J, Iglesias, M. Talon and R. Borriss. 2007. Tryptophan- Dependent
Production of Indole-3-Acetic Acid (IAA) Affects Level of Plant Growth Promotion by Bacillus amyloliquefaciens FZB42. Molecular Plant- Microbe Interaction. 20 :619-626.

Illmer, P., A. Barbato, and F. Schinner. 1995. Solubilizing of Hardly Soluble AIPO4 with P-solubilizing Microorganism. Soil Biol. Biochem. 27 :265-270.

Kundu, B.S and A.C. Gaur. 1980. Establishment of Nitrogen Fixing and Phosphate Solubilizing Bacteria in Rhizosphere and their Effect on Yield and Nutrient Uptake of Wheat Crop. J. Plant Soil. 57: 223-230.

Lestari, P, D. N, Susilowati, and E. I. Riyanti. 2007. Pengaruh Hormon Asam Indol Asetat yang Dihasilakan oleh Azospirillum sp. Terhadap Perkembangan Akar Padi. J. Agro Biogen. 3(2) : 66-71.

Leveau, J. H and S. E. Lindow. 2004. Utilization Of Plant Hormone Indole3- Acetic Acid For Growth By Pseudomonas putida Strain 1290. American Society For Microbiology.1(5) : 2365- 2370.

Patil N.B, M. Gajbhiye, S.S. Ahiwale, A.B. Gunjal, and B.P Kapadnis. 2011. Optimization of indole 3 -acetic acid (IAA) production by Acetobacter diazotrophicus L1 isolated from sugarcane. J Environ Sci 2 (1): 307- 314.

Prescott, H. 2002. Laboratory Exercise in Microbiology. Tha-Graw Hil Company. New York.

Rismunandar. 1999. Hormon Tanaman dan Ternak. Jakarta: Penebar Swadaya.

Rosenblueth, M and E. Martínez-Romero. 2006. The American Phytopathological Society. MPMI Vol. 19, No. 8 :827-837.

Tarabily, K., A. H. Nassar, and K. Sivasithamparam. 2003. Promotion Of Plant Growth By An Auxin- Producing Isolate Of The Yeast Williopsis Saturnus Endophytic In Maize Roots. The Sixth U. A. E University Research Conference. p 60- 69 . 
Thakuria D., N.C. Talukdar, C. Goswami, S. Hazarika, R.C. Boro, and M.R. Khan. 2004. Characterization and Screening of Bacteria from Rhizosphere in Rice Grown in Acidic Soil from Assam. J. Curr. Sci. $86: 978$ - 985.

Vasques, MM, S. Cesae, R. Azcon, J. M. Barea.2000. Interaction betweeen Arbuscular Mychorrizal Fungi and other Microbial Inoculation (Azosprilium, Pseudomonas, Trichoderma) and their Effects on Microbial Population and Enzyme Activities in the Rhizophere of Maize Plants. Appl soil Ecol. 15:261-272.
Vessey, J.K. 2003. Plant Growth Promoting Rhizobachteria as Biofertilizer. Plant and Soil. 225: 571-586. 